Tinjauan Pustaka

Vol 6 No. 2, Oktober 2017

ISSN 2460-8742

http://journal.unair.ac.id/journal-of-orthopaedic-and-traumatology-surabaya-media-104.html

\title{
CLINICAL APPLICATION OF BONE MORPHOGENETIC PROTEIN ON FRACTURE HEALING PROCESS
}

\author{
Riko Febrian Kunta Adjie ${ }^{1^{*}}$ \\ ${ }^{1}$ Dokter Umum Internship RSUD Ben Mboi, Ruteng, Nusa Tenggara Timur
}

*Korespondensi : Riko Febrian Kunta Adjie, Dokter Umum Internship RSUD Ben Mboi, Jln. DR. Soetomo No. 1, Ruteng. Kelurahan Watu, Kecamatan Langke Rembong, Kab. Manggarai 86511 E-mail: rikokuntaadjie@gmail.com

\begin{abstract}
ABSTRAK
Pada proses penyembuhan fraktur, sering terjadi delayed union maupun non-union. Penggunaan Bone Morphogenetic Proteins (BMP) menjadi salah satu solusi untuk masalah ini. Beberapa penelitian membuktikan bahwa BMP membantu meningkatkan regenerasi penyembuhan fraktur dengan kasus sulit pada sejumlah pasien. Tinjauan pustaka ini membahas pengenalan BMP dan efisiensi daripada penggunaan klinis BMP. Saat ini, rhBMP-2 dan rhBMP7 menunjukkan hasil klinis yang signifikan namun subfamili BMP lainnya masih dalam penelitian. Kata Kunci: bone morphogenetic protein, fraktur, growth factor, penyembuhan tulang
\end{abstract}

\begin{abstract}
Delayed union or non-union often occurs in bone healing fracture process. The clinical application of Bone Morphogenetic Proteins (BMPs) has helped an increasing number of patients achieve bone regeneration in clinical area lacking simple solutions for difficult bone healing situations. Many researchs has proved that BMPs improved fracture healing regeneration. In this review article, introduction and current clinical issues are summarized on efficacy and function of BMPs. Currently, rhBMP-2 and rhBMP-7 have shown clinical significance but other subfamily members of BMPs still lacked of evidence.

Keyword: bone morphogenetic protein, fracture, growth factor bone, healing
\end{abstract}

\section{PENDAHULUAN}

Secara umum, proses penyembuhan fraktur terjadi melalui penyembuhan tidak langsung ataupun langsung. Penyembuhan tidak langsung yaitu melalui serangkaian proses yang terjadinya formasi kalus. Sedangkan penyembuhan langsung terjadi tanpa terbentuknya formasi kalus. Kalus yang terkalsifikasi membungkus dua fragmen patahan yang pada tahap ini disebut union. Namun pada tahap union, penyembuhan belum sempurna karena pergerakan fragmen masih dapat terjadi sehingga tidak aman untuk mendapatkan stres. Konsolidasi merupakan tahap penyembuhan yang sempurna, kalus sudah terosifikasi sehingga kekuatan tulang untuk menerima beban sudah kembali. ${ }^{1}$

Terkadang proses penyembuhan fraktur ini terganggu dan tulang terlambat menyatu (delayed union) atau mungkin gagal 


\section{Tinjauan Pustaka}

Vol 6 No. 2, Oktober 2017

http://journal.unair.ac.id/journal-of-orthopaedic-and-traumatology-surabaya-media-104.html

menyatu atau disebut non-union. Komplikasi

ini dapat masa hospitalisasi lebih panjang dan membutuhkan intervensi lebih disertai ketidaknyamanan dan biaya yang meningkat. Dalam hal ini faktor-faktor seperti suasana lingkungan sekitar sel yang memadai, growth faktor yang cukup, stabilitas mekanik dan pembentukan matriks mempengaruhi kecepatan penyembuhan fraktur. Sekitar 5$30 \%$ pasien kekurangan faktor ini, sehingga menyebabkan timbulnya komplikasi delayed union atau mungkin non-union. ${ }^{2}$

Tatalaksana non-union sendiri sebenarnya tergantung pada etiologi yang mendasarinya. Non-union hipertrofik dapat ditatalaksana dengan revisi pembedahan dengan mengkonstruksi ulang untuk mencegah pergerakan pada lokasi fraktur. Pasien dengan masalah metabolik atau endokrin dapat dilakukan pemeriksaan laboratorium untuk menentukan kadar serum kalsium, fosfat, alkaline fosfatase, vit. D, dan level hormon thyroid. Infeksi harus dapat disingkirkan melalui pemeriksaan laju endap darah dan CRP. Tatalaksana pada non-union terinfeksi terdiri dari debridemen dan antibiotik. Pada kasus Non-union atrofik dapat diberikan suplemental bone graft, termasuk autograft, allograft, demineralized bone matrix, BMP, synthetic bone graft, dan stem cells. ${ }^{1}$

Penyembuhan fraktur dan waktu untuk mencapai union dapat ditingkatkan dengan stimulasi biofisika atau pemberian substansi biologik seperti autolog bone grafts atau platelet rich plasma (PRP). Studi terkini mengenai mekanisme penyembuhan fraktur menghasilkan penemuan-penemuan spesifik mengenai komponen penting dalam penyembuhan fraktur, sebagai contoh hormon parathyroid, hypoxia-inducible factor $1 \alpha(\mathrm{HIF}-1 \alpha)$ dan bone morphogenetic proteins (BMPs). ${ }^{3}$ BMP yang merupakan growth factor berhasil menarik perhatian peneliti-peneliti. Ditemukan oleh Marshall Urist $^{4}$ pada tahun 1964, sekarang dapat dimurnikan dari matriks tulang. Secara molekular, BMP menunjukkan kemampuan menginduksi diferensiasi sel progenitor menjadi tulang rawan yang kemudian menjadi tulang matur. ${ }^{1}$ Pemberian BMP yang merupakan komponen aktif pada tulang secara in vivo dapat menginduksi pembentukan tulang de novo pada tempat ektopik. Artikel ini akan membahas penggunaan klinik BMP dalam proses penyembuhan fraktur. 


\section{BMPs}

BMPs merupakan subfamili dari transforming growth factor- $\beta \quad(T G F-\beta)$ superfamily. Selama ini telah ditemukan 20 protein yang berbeda dinamakan BMP dalam tubuh manusia, namun tidak semuanya bersifat osteogenik. BMP yang osteogenik dapat dibagi menjadi beberapa subgrup, menurut kesamaan rantai asam aminonya ${ }^{5,6}$ : BMP-2 dan BMP-4 menjadi satu subgrup; BMP-5, BMP-6, BMP-7, BMP-8 pada subgrup yang kedua; BMP-9 dan BMP-10 membentuk subgrup yang ketiga. BMP family yang lain tidak memiliki kemampuan osteogenik. ${ }^{5,7}$

Pada tulang, BMPs diproduksi oleh sel osteoprogenitor, osteoblast, chondrocytes, dan platelet. ${ }^{8,9}$ Setelah dilepas, matriks ekstraseluler menjadi tempat penyimpanan sementara BMP. Efek regulasi dari BMP bergantung pada tipe sel target, tahap diferensiasi, konsentrasi lokal BMP itu sendiri, dan interaksi dengan protein yang disekresi lainnya. BMP menginduksi sekuensial pembentukan chondrogenesis, osteogenesis, angiogenesis, dan kontrol sintesis matriks ekstraseluler. ${ }^{6}$

\section{Penggunaan Klinis BMP}

Berdasarkan studi hewan dan trial preklinik, beberapa studi menunjukkan efektivitas BMP dalam mempercepat regenerasi tulang dan penyembuhan tulang. Namun kerja BMP membutuhkan faktor lokal dan cara pemberian yang tepat. Selain itu waktu paruh BMP yang singkat juga perlu dipertimbangkan. Beberapa cara pemberian BMP telah dikembangkan untuk mengatasi keterbatasan ini. ${ }^{10-4}$
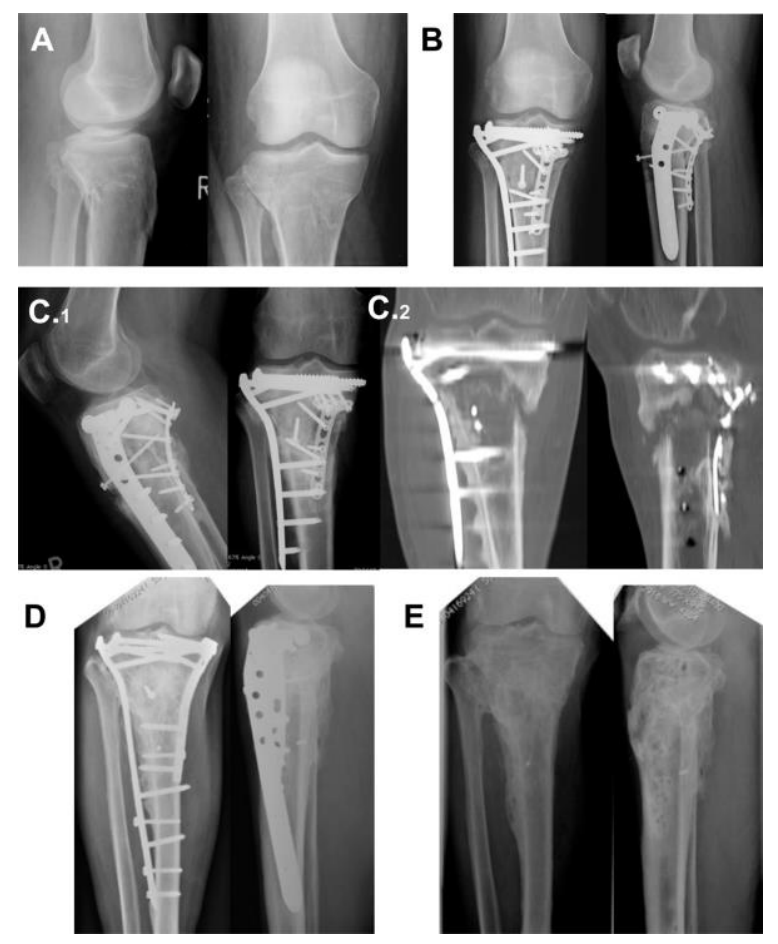

Gambar 1. Terapi sukses pada kasus nonunion dengan rhBMP-2 (A) radiografi setelah fraktur; (B) Tatalaksana fraktur tanpa rhBMP-2; (C) Terjadi non-union (C.1) dengan CT-scan pada C.2; (D) Penyembuhan setelah revisi dengan re-osteosintesis dan rhBMP-2; (E) Implant removal. ${ }^{10}$ 


\section{Tinjauan Pustaka}

Vol 6 No. 2, Oktober 2017

http://journal.unair.ac.id/journal-of-orthopaedic-and-traumatology-surabaya-media-104.html

Penggunaan klinis rhBMP-2 (dibotermin alfa) dengan merk produk InductOs dan InFUSE, produk ini dapat dilepas secara lambat. Govender et al mengevaluasi efek rhBMP-2 pada 450 pasien dengan fraktur terbuka tibia secara prospektif. Implantasi rhBMP-2 pada sponge kolagen menunjukkan angka union yang lebih tinggi, mempercepat union, penyembuhan luka lebih baik, menurunkan angka infeksi dan angka intervensi sekunder yang lebih rendah pada kelompok yang diterapi dengan rhBMP-2. Studi ini menyimpulkan pengunaan rhBMP-2 menghasilkan hasil yang menjanjikan. ${ }^{10}$

Penggunaan klinis lain BMP, yaitu rhBMP-7 dengan merk Osigraft dan OP-1 Putty, yang dikemas dalam 1 g kolagen bovine. Pada uji coba acak menunjukkan efek positif rhBMP-7 pada kasus non-union scaphoid dan defek fibular. Pemberian rhBMP-7 menunjukkan formasi tulang yang lebih baik dan terbentuk bridging pada defek segmental dibandingkan dengan kontrol. Giannoudis dan Tzioupis mengevaluasi indikasi dan efektivitas terapi rhBMP-7. ${ }^{12}$ Penggunaan rhBMP-7 dapat digunakan pada kasus non-union, augmentasi pada kasus fraktur periprostesis dan osteotomi, mempercepat penyembuhan fraktur pada kasus rekonstruksi acetabular, distraksi osteogenesis, free fibular graft, dan arthrodesis sendi. Persentase keberhasilan mencapai $82 \%$ (535 dari 653 kasus). ${ }^{12}$ Ristiniemi et al mengintervensi 20 pasien dengan fraktur distal tibia yang distabilisasi dengan fiksasi eksternal dan rh-BMP-7 dalam kolagen bovine. Penyembuhan fraktur terjadi lebih cepat. ${ }^{17}$

Potensi rhBMP-2 dan rhBMP-7 dibandingkan secara in vitro dan in vivo. ${ }^{18}$ In vitro, kedua agen ini meningkatkan produksi alkaline phosphatase yang mana mengindikasikan diferensiasi osteogenik. Produksi alkaline phospates terlihat lebih tinggi pada kelompok rhBMP-2 daripada kelompok rhBMP-7. Namun, secara in vivo rhBMP7 memproduksi ossicles yang lebih besar, yang merupakan komponen mineral dan tulang. Studi in vivo lainnya menunjukkan rhBMP-2 lebih poten daripada rhBMP-7. ${ }^{20}$ Hasil kontradiksi fakta ini mungkin dikarenakan mekanisme cara kerja BMPs yang berbeda dan cara pemberiannya.

Platelet juga memiliki komponen BMP dan pemberian PRP merupakan salah satu aplikasi BMPs. Namun Calori et al mengatakan bahwa pemberian rhBMP-7 masih lebih superior ketimbang penggunaan PRP. ${ }^{11}$ 


\section{Tinjauan Pustaka}

Vol 6 No. 2, Oktober 2017

ISSN 2460-8742

http://journal.unair.ac.id/journal-of-orthopaedic-and-traumatology-surabaya-media-104.html

BMP-6 dan BMP-9 yang merupakan anggota famili BMP lainnya dikatakan lebih memiliki kemampuan osteogenik yang lebih baik bila dibandingkan dengan BMP-2 dan

\section{Efek Samping BMPs}

Beberapa efek samping telah dikemukakan dalam penggunaan rhBMP. Terutama bila digunakan dalam dosis suprafisiologis, pembentukan tulang ektopik dan stimulasi sel kanker masih dalam studi. Recombinant BMP-2 saat ini tidak menunjukkan adanya hubungan dengan kanker pankreas pada studi lebih dari 90.000 pasien. Terbentuknya tulang ektopik dikatakan dapat terjadi apabila digunakan dalam dosis sangat tinggi pada percobaan binatang. Namun BMP tetap menjadi modalitas terapi yang poten dalam menunjang kesembuhan fraktur dengan efek samping yang ringan apabila digunakan dengan benar. ${ }^{19}$

Selain itu beberapa efek samping negatif yang dilaporkan setelah penggunaan rhBMP-2 termasuk infeksi, osteolisis, ejakulasi retrograde, dan respon imun. Hal ini juga dilaporkan terkait dengan dosis suprafisiologis. Beberapa uji coba menggunakan dosis rhBMP-2 dalam rentang dosis 10-12 mg pada terapi defek tulang panjang. ${ }^{21}$
BMP-7.61 namun hal ini masih terbatas dalam penelitian pada mencit, belum secara adekuat terbukti pada manusia.

Literatur saat ini menyarankan 1-2 mikrogram BMP/kg berat badan. ${ }^{22}$

\section{Blok Antagonis BMPs}

Namun adanya BMP tidak menjamin efisiensi penyembuhan fraktur. Walaupun adanya BMP sangat penting dalam proses penyembuhan fraktur, BMP sangat bergantung dengan adanya faktor lokal baik inhibitor maupun stimulator yang mempengaruhi aktivitas BMP itu sendiri. ${ }^{20}$

Karena rhBMP masih memiliki kekurangan, pencarian terhadap alternatif lain masih dilakukan. Memblok antagonis BMP merupakan salah satu alternatifnya. Dengan menginhibisi antagonis BMP pada fase kalus penyembuhan fraktur. Hanya saja sangat sedikit literatur yang membahas mengenai manipulasi antagonis BMP untuk membantu penyembuhan fraktur pada manusia. $^{20}$ 


\section{Tinjauan Pustaka}

Vol 6 No. 2, Oktober 2017

http://journal.unair.ac.id/journal-of-orthopaedic-and-traumatology-surabaya-media-104.html

\section{Kesimpulan}

Efektivitas penggunaan BMPs dalam membantu penyembuhan fraktur terbukti menunjukkan efek positif. Beberapa penelitian uji coba acak telah menyimpulkan bahwa BMP membantu penyembuhan kasus delayed dan non-union.

BMP yang saat ini digunakan dalam proses penyembuhan fraktur adalah BMP-2 dan BMP-7. BMP lain seperti BMP-6 dan BMP-9 menunjukan lebih poten dan mungkin lebih efektif dalam tatalaksana delayed dan non-union, namun hal ini masih terbatas dalam penelitian in vivo. Tidak

\section{Referensi}

1. Salomon L, Warwick D, Nayagam S. Apley's System of Orthopaedics and Fractures. $9^{\text {th }}$ ed. London: Hodder Arnold; 2010.

2. Dimitriou R, Tsiridis E, Giannoudis PV (2005) Current concepts of molecular aspects of bone healing. Injury 36:13921404.

3. Komatsu DE, Warden SJ (2010) The control of fracture healing and its therapeutic targeting: improving upon nature. J Cell Biochem 109:302-311.

4. Urist MR (1965) Bone: formation by autoinduction. Science 150:893-899.

5. Li JZ, Li H, Sasaki T, Holman D, Beres B, Dumont RJ, Pittman DD, Hankins GR, Helm GA (2003) Osteogenic potential of five different recombinant human bone morphogenetic protein adenoviral vectors in the rat. Gene Ther 10:1735-1743. menutup kemungkinan bahwa di masa mendatang bila subfamili BMP osteogenik lain seperti yang telah dibahas, dapat digunakan dalam praktek klinis sehari-hari.

BMP juga memiliki beberapa efek samping, namun hal ini tidak terlalu mengkhawatirkan selama tidak digunakan dalam dosis berlebihan dan jangka panjang. Perlu diingat juga bahwa terdapat faktor lain yang mempengaruhi kerja BMP karena disebabkan adanya antagonis BMP itu sendiri dalam jaringan.

6. Tsiridis E, Upadhyay N, Giannoudis P (2007) Molecular aspects of fracture healing: which are the important molecules? Injury 38 (Suppl 1):S11-S25

7. Miyazono K, Kamiya Y, Morikawa M (2010) Bone morphogenetic protein receptors and signal transduction. J Biochem 147:35-51.

8. Sipe JB, Zhang J, Waits C, Skikne B, Garimella R, Anderson HC(2004) Localization of bone morphogenetic proteins (BMPs)-2, -4, and -6 within megakaryocytes and platelets. Bone 35:1316-1322.

9. Pecina M, Vukicevic S (2007) Biological aspects of bone, cartilage and tendon regeneration. Int Orthop 31:719720.

10. Govender S, Csimma C, Genant HK, Valentin-Opran A, Amit Y, Arbel R, et al. 2002. Recombinant human bone 
morphogenetic protein-2 for treatment of open tibial fractures: a prospective, controlled, randomized study of four hundred and fifty patients. J Bone Joint Surg Am 84-A:2123- 2134.

11. Calori GM, Tagliabue L, Gala L, d'Imporzano M, Peretti g, Albisetti W (2008) Application of rhBMP-7 and platelet-rich plasma in the treatment of long bone non-unions: a prospective randomised clinical study on 120 patients. Injury 39:1391-1402.

12. Giannoudis PV, Tzioupis C. (2005) Clinical applications of BMP-7: the UK perspective. Injury 36(Suppl 3):S47-S50

13. Katayama Y, Matsuyama Y, Yoshihara $\mathrm{H}$, et al. (2009). Clinical and radiographic outcomes of posterolateral lumbar spine fusion in humans using recombinant human bone morphogenetic protein-2: an average five-year followup study. Int Orthop 33:1061-1067.

14. Varady P, Li JZ, Cunningham M, Beres EJ, et al. (2001). Morphologic analysis of BMP-9 gene therapy-induced osteogenesis. Hum Gene Ther 12:697710.

15. Yilgor P, Hasirci N, Hasirci V. (2010). Sequential BMP-2/BMP-7 delivery from polyester nanocapsules. J Biomed Mater Res A 93:528-536.

16. Boerckel JD, Kolambkar YM, Dupont KM, Uhrig BA, et al. (2011). Effects of protein dose and delivery system on BMP-mediated bone regeneration. Biomaterials 32:5241-5251.

17. Ristiniemi J, Flinkkilä T, Hyvönen P, Lakovaara M, Pakarinen H, Jalovaara P. (2007) RhBMP-7 accelerates the healing in distal tibial fractures treated by external fixation. J Bone Joint Surg Br 89:265-272.

18. Barr T, McNamara AJ, Sándor GK, Clokie CM, Peel SA. (2010) Comparison of the osteoinductivity of bioimplants containing recombinant human bone morphogenetic proteins 2 (Infuse) and 7 (OP-1). Oral Surg Oral Med Oral Pathol Oral Radiol Endod 109:531-540.

19. Tazaki J, Murata M, Akazawa T, Yamamoto M, Ito K, Arisue M, Shibata T, Tabata Y. (2009) BMP-2 release and dose-response studies in hydroxyapatite and beta-tricalcium phosphate. Biomed Mater Eng 19:141-146.

20. Dean DB, Watson JT, Moed BR, Zhang $\mathrm{Z}$ (2009) Role of bone morphogenetic proteins and their antagonists in healing of bone fracture. Front Biosci 14:28782888.

21. A.L. Jones, R.W. Bucholz, M.J. Bosse, S.K. Mirza, T.R. Lyon, L.X. Webb, A.N. Pollak, J.D. Golden, A. Valentin-Opran, Group BMPEiSfTT-AS, Recombinant human BMP-2 and allograft compared with autogenous bone graft for reconstruction of diaphyseal tibial fractures with cortical defects. A randomized, controlled trial, J. Bone Joint Surg. Am. 88 (2006) 1431-1441.

22. J.M. Wozney, V. Rosen, A.J. Celeste, L.M. Mitsock, M.J. Whitters, R.W. Kriz, R.M. Hewick, E.A. Wang, Novel regulators of bone formation: molecular clones and activities, Science 242 (1988) 1528-1534. 